

\title{
Effects of stream acidification on fungal biomass in decaying beech leaves and leaf palatability
}

Olivier Dangles, Eric Chauvet

\section{To cite this version:}

Olivier Dangles, Eric Chauvet. Effects of stream acidification on fungal biomass in decaying beech leaves and leaf palatability. Water Research, 2003, Vol. 37 ( $\left.\mathrm{N}^{\circ} 3\right)$, pp. 533-538. 10.1016/S00431354(02)00359-7 . hal-01333517

\section{HAL Id: hal-01333517 https://hal.science/hal-01333517}

Submitted on 17 Jun 2016

HAL is a multi-disciplinary open access archive for the deposit and dissemination of scientific research documents, whether they are published or not. The documents may come from teaching and research institutions in France or abroad, or from public or private research centers.
L'archive ouverte pluridisciplinaire HAL, est destinée au dépôt et à la diffusion de documents scientifiques de niveau recherche, publiés ou non, émanant des établissements d'enseignement et de recherche français ou étrangers, des laboratoires publics ou privés. 


\section{Open Archive TOULOUSE Archive Ouverte (OATAO)}

OATAO is an open access repository that collects the work of Toulouse researchers and makes it freely available over the web where possible.

This is an author-deposited version published in : http://oatao.univ-toulouse.fr/ Eprints ID : 9639

To cite this version : Dangles, Olivier and Chauvet, Eric Effects of stream acidification on fungal biomass in decaying beech leaves and leaf palatability. (2003) Water Research, Vol. 37 (N³). pp. 533-538. ISSN 0043-1354

Any correspondence concerning this service should be sent to the repository administrator: staff-oatao@ listes-diff.inp-toulouse.fr 


\title{
Effects of stream acidification on fungal biomass in decaying beech leaves and leaf palatability
}

\author{
O. Dangles ${ }^{\mathrm{a}, *}$, E. Chauvet ${ }^{\mathrm{b}}$ \\ ${ }^{a}$ Faculté des Sciences \& Techniques, Institut de Recherche en Biologie de l'Insecte, IRBI UMR CNRS 6035, Avenue-Monge-Parc de \\ Grandmont, F-37200 Tours, France \\ ${ }^{\mathrm{b}}$ Centre d'Ecologie des Systèmes Aquatiques Continentaux, 29 Rue Jeanne Marvig, F-31055 Toulouse 04, France
}

\begin{abstract}
We examined the effect of surface water acidification on rates of decomposition, ergosterol concentrations (as a measure of fungal biomass), and palatability to shredders of common beech leaves (Fagus sylvatica L.) in five mountain streams $(\mathrm{pH}$ 4.7-7.1). Leaf decomposition was significantly faster in the circumneutral streams ( $\mathrm{pH}$ 6.4-7.1; $k \geqslant 0.00175 \mathrm{~d}^{-1}$ ), when compared to acidic streams ( $\mathrm{pH} 4.7-4.9 ; k \leqslant 0.00100 \mathrm{~d}^{-1}$ ). Fungal biomass showed no particular trend along the acidification gradient except that it peaked earlier in the stream closest to neutrality. Leaf palatability, measured as the feeding activity of the leaf-shredding amphipod Gammarus fossarum Koch, varied with the exposure time in the streams. Except for the higher palatability of leaves exposed during 6 weeks at the highest $\mathrm{pH}$, patterns among streams were mostly similar. These results suggest that reduced processing rates in the most acidic streams were not related to differences in fungal biomass associated with decomposing leaves and that microbial conditioning was only slightly delayed by acidification. Possible effects of low $\mathrm{pH}$ and related variables $(\mathrm{Ca}, \mathrm{Al})$ on microbial decomposition and detritivorous macroinvertebrates are discussed to clarify the inhibition of beech leaf decomposition in the studied systems.
\end{abstract}

Keywords: Beech leaf litter decomposition; Freshwater streams; Water chemistry; pH; Fungal biomass

\section{Introduction}

During the last decades, acid precipitation has been demonstrated to induce deleterious effects on both structure and function of headwater streams [1,2]. One of the major changes in ecosystem functioning is the alteration of leaf litter decomposition, a key process in woodland streams $[1,3]$. In the Vosges Mountains (N-E France), the forest floor of the valleys is covered with autumn-shed beech leaves (Fagus sylvatica L.) throughout the year. Except when the leaves are immobilized on the ground by snow, they are sporadically blown into the stream beds where they accumulate either against

\footnotetext{
*Corresponding author. Tel.: + 33-2-47-36-73-50.

E-mail address: olivier.dangles@univ-tours.fr (O. Dangles).
}

stones or in detrital pools. Beech leaves provide the bulk of particulate organic matter for these streams. The study of the agents involved in their decomposition thus appears of primary importance in understanding the energy flow in acidified ecosystems. A recent study which compared breakdown rates of beech leaves in coarse- and fine-mesh bags indicated that direct microbial contribution to leaf mass loss was small, i.e. less than $20 \%$ in the circumneutral streams [1]. However, microbes may indirectly account for the lower decomposition rates observed in acidic streams since effects on microbial species composition or microbial metabolism may alter leaf palatability for invertebrate detritivores [4].

Much research has been devoted to the impact of freshwater acidification on leaf litter quality, and it 
indicates that acidification reduces the nutritional value of detrital food through alterations of the associated microbial communities and changes in leaf nutrient content $[3,4]$. Most of these studies relied on indicators of total microbial biomass or activity such as ATP content [5] and respiration rate [6] from fungi, bacteria, algae and Protozoa. More specific measurements include conidial and bacterial counts [3] and bacterial production rate [2]. Some studies have been specifically performed on aquatic hyphomycetes because of their role in conditioning leaves for consumption by invertebrate detritivores $[3,4,7]$.

These studies do not allow an unequivocal conclusion concerning the effects of low $\mathrm{pH}$ on aquatic fungal communities. On one hand, several studies showed these fungi to prefer strongly or slightly acidic to neutral conditions $[8,9]$. On the other hand, low $\mathrm{pH}$ are reported to have deleterious effects on aquatic hyphomycetes, in terms of species richness [10,11], leaf maceration activity [12] or conidial production [4]. Last, some authors concluded that aquatic hyphomycetes were neither especially favored nor negatively affected, and were even remarkably resistant to the effects of acidification [13]. These equivocal results may be partly explained by the highly variable protocols used, both in terms of exposure (natural vs. artificial acid waters) and fungi-related methodology (e.g. microscopic scanning of leaf surface vs. whole leaf measurements).

In this context, we think that the ecological relevance of many laboratory studies may be questioned due to the divergence of the experimental conditions from natural situations (see Ref. [14]) and that the biomass and implication of leaf-colonizing fungi must be specifically evaluated using appropriate methods.
The objective of the present study was to investigate the influence of stream water acidity on fungal colonization of leaf litter and litter palatability to one invertebrate detritivore species Gammarus fossarum (КосH). This species and its congeners are frequently used in laboratory studies because they are often very abundant in streams, available throughout the year and easy to keep in laboratory conditions. Furthermore, $G$. fossarum is always and typically present in neutral streams of the Vosges Mountains where it dominates detritivore assemblages but it is eradicated when water $\mathrm{pH}$ drops below 6.2 [1]. We selected five headwater streams subject to atmospheric acidic deposition differing in $\mathrm{pH}$ and concentrations of aluminium, calcium and nitrates. Although some of these elements have been implicated in the toxicity of acidic waters towards aquatic life [15], very little is known about their specific effects on fungi associated with leaf litter.

\section{Material and methods}

\subsection{Site description}

The experiment was conducted in the Vosges Mountains ( $\mathrm{N}-\mathrm{E}$ France), a massif composed of sandstone and granite with forested catchments dominated by silver fir (Abies alba Karst.), Norway spruce (Picea abies Karst.), and common beech (F. sylvatica). An important characteristic of the study area is that small-scale differences (sometimes between even adjacent streams) in mineral composition of the underlying bedrock produce marked differences in buffering capacities, ion content and, consequently, degrees of acidification and mineralization sometimes of even adjacent streams [16].

Table 1

Mean values of the water temperature and physico-chemical of the five streams from November 1999 to April 2000 ( $n=7)$

\begin{tabular}{|c|c|c|c|c|c|}
\hline Streams & GS & $\mathrm{BR}$ & MR & HR & LM \\
\hline $\mathrm{pH}$ & $\begin{array}{l}4.7 \\
(4.3 / 4.9)\end{array}$ & $\begin{array}{l}4.9 \\
(4.6 / 5.3)\end{array}$ & $\begin{array}{l}5.7 \\
(5.1 / 6.1)\end{array}$ & $\begin{array}{l}6.4 \\
(5.8 / 6.5)\end{array}$ & $\begin{array}{l}7.1 \\
(6.8 / 7.2)\end{array}$ \\
\hline Temperature $\left({ }^{\circ} \mathrm{C}\right)$ & $\begin{array}{l}4.5 \\
(2.1 / 6.0)\end{array}$ & $\begin{array}{l}2.9 \\
(0.2 / 5.0)\end{array}$ & $\begin{array}{l}3.1 \\
(0.2 / 5.0)\end{array}$ & $\begin{array}{l}3.3 \\
(0.3 / 5.2)\end{array}$ & $\begin{array}{l}4.6 \\
(2.3 / 6.1)\end{array}$ \\
\hline Conductivity $(\mu \mathrm{S} / \mathrm{cm})$ & $\begin{array}{l}31 \\
(30 / 35)\end{array}$ & $\begin{array}{l}17 \\
(14 / 19)\end{array}$ & $\begin{array}{l}18 \\
(15 / 21)\end{array}$ & $\begin{array}{l}23 \\
(18 / 29)\end{array}$ & $\begin{array}{l}70 \\
(50 / 91)\end{array}$ \\
\hline $\mathrm{ANC}(\mu \mathrm{Eq} / \mathrm{L})$ & $\begin{array}{l}-17 \\
(-29 /-6)\end{array}$ & $\begin{array}{l}-7 \\
(-26 / 0)\end{array}$ & $\begin{array}{l}20 \\
(0 / 36)\end{array}$ & $\begin{array}{l}70 \\
(27 / 116)\end{array}$ & $\begin{array}{l}444 \\
(225 / 603)\end{array}$ \\
\hline Total $\mathrm{Al}(\mu \mathrm{g} / \mathrm{L})$ & $\begin{array}{l}765 \\
(720 / 900)\end{array}$ & $\begin{array}{l}262 \\
(250 / 400)\end{array}$ & $\begin{array}{l}153 \\
(130 / 200)\end{array}$ & $\begin{array}{l}121 \\
(60 / 160)\end{array}$ & $\begin{array}{l}31 \\
(20 / 30)\end{array}$ \\
\hline $\mathrm{Ca}^{2+}(\mathrm{mg} / \mathrm{L})$ & $\begin{array}{l}1.3 \\
(1.3 / 1.4)\end{array}$ & $\begin{array}{l}1.0 \\
(0.9 / 1.0)\end{array}$ & $\begin{array}{l}1.3 \\
(1.1 / 1.3)\end{array}$ & $\begin{array}{l}1.7 \\
(1.6 / 1.8)\end{array}$ & $\begin{array}{l}7.6 \\
(7.3 / 8.0)\end{array}$ \\
\hline $\mathrm{NO}_{3}^{-}(\mathrm{mg} / \mathrm{L})$ & $\begin{array}{l}6.7 \\
(6.6 / 6.8)\end{array}$ & $\begin{array}{l}1.6 \\
(1.5 / 1.7)\end{array}$ & $\begin{array}{l}1.5 \\
(1.4 / 1.7)\end{array}$ & $\begin{array}{l}0.9 \\
(0.8 / 1.1)\end{array}$ & $\begin{array}{l}4.0 \\
(3.8 / 4.1)\end{array}$ \\
\hline
\end{tabular}

Range is given in brackets. $\mathrm{ANC}=$ acid neutralizing capacity. 
On the basis of previous results [1], we selected five firstand second-order streams contrasting in acidification levels and concentrations of aluminium, calcium and nitrates (Table 1). Gentil Sapin (GS) and Bas-Rupts (BR) were the most acidified streams. They had rather similar $\mathrm{pH}$ and calcium contents, but total aluminium concentrations in GS were three times higher than in BR due to the alumine-rich sandstone bedrock of GS and the granitic bedrock of BR. Moyens-Rupts (MR) was a moderately acidic stream which mainly differed from BR by its higher $\mathrm{pH}$. Two non-acidified streams, HautsRupts (HR) and La Maix (LM), showed a circumneutral $\mathrm{pH}$ but strongly differed with respect to their acid neutralising capacities (ANC) and calcium concentrations ( 70 vs. $444 \mu \mathrm{Eq} / \mathrm{L}$ and 1.7 vs. $7.6 \mathrm{mg} / \mathrm{L}$, respectively) which were much higher in LM. Water temperature patterns in the five streams were similar $\left(0.2-6.1^{\circ} \mathrm{C},[1]\right)$. Physical characteristics of the streams are detailed in Dangles et al. [17]. Briefly, the five streams had very similar geomorphologic characteristics, especially in terms of water depth $(\leqslant 0.60 \mathrm{~m})$, stream width $(\leqslant 3.30 \mathrm{~m})$ and gradient $(>9 \%)$. Stream bed was mainly composed by cobble/boulder riffles.

\subsection{Leaf bag samples and fungal biomass}

In November 1999, leaves of common beech were collected on the trees just before abscission. Three grams of air-dried leaves were enclosed in $5-\mathrm{mm}$ mesh plastic bags $\left(15 \times 10 \mathrm{~cm}^{2}\right), 18$ of which were submerged at each site on 27 November 1999. The bags were placed in a submerged polyethylene cage $\left(5 \times 5 \mathrm{~cm}^{2}\right.$ openings $)$ anchored to the bottom with large stones. Three replicate leaf bags were recovered after 2, 6, 10, 14, 18 and 22 weeks of exposure. In the laboratory, 2-cm diameter discs were cut from leaves soaked in the corresponding stream water, and used for leaf consumption experiments (see below). The remaining material was frozen $\left(-72^{\circ} \mathrm{C}\right)$, later freeze-dried and crushed into small fragments for subsequent analysis. The organic matter content of leaves was determined by ignition at $550^{\circ} \mathrm{C}$ for $4 \mathrm{~h}$. Ergosterol, a membrane sterol largely restricted to eumycotic fungi, was used as an indicator of metabolically active fungal biomass [18]. It was extracted from 180 to $200 \mathrm{mg}$ leaf samples by $30 \mathrm{~min}$ refluxing in alcoholic base, purified by solid-phase extraction and quantified by High Pressure Liquid Chromatography [18].

\subsection{Leaf consumption experiments}

To determine the effect of $\mathrm{pH}$ and associated variables $\left(\mathrm{Ca}, \mathrm{Al}\right.$ and $\mathrm{NO}_{3}$ ) on leaf palatability for invertebrate detritivores, feeding experiments were conducted using beech leaves recovered at each sampling date. Palatability was defined as leaf consumption by the shredding amphipod, G. fossarum. Animals were collected with a hand net from LM stream. The animals were then carried to the laboratory and acclimated to laboratory conditions $\left(8 \pm 1{ }^{\circ} \mathrm{C}\right.$ and natural daylight period) during $24 \mathrm{~h}$ in aquaria containing oxygenated water from LM. Five gammarids and five leaf discs previously cut (see above) were then placed in plastic cylinders $(\phi=6 \mathrm{~cm}$, $h=5 \mathrm{~cm}$ ) covered with a $0.3-\mathrm{mm}$ mesh screen on both ends. The initial AFDM of the leaf material was determined on five additional discs. Three replicate cylinders with animals, each corresponding to a different leaf bag, and one control without animals were used for each of the five treatments. All cylinders were placed together in an aquarium filled with filtered water from LM and aerated with an aquarium pump. After 6 days, the remaining leaf fragments were removed, oven-dried $\left(105^{\circ} \mathrm{C}, 24 \mathrm{~h}\right)$ and ashed $\left(550^{\circ} \mathrm{C}, 4 \mathrm{~h}\right)$ separately. Consumed leaf mass was calculated as the difference between the initial and remaining AFDM. This protocol was repeated at each leaf bag recovering date (i.e. after 2, 6 , 10, 14, 18 and 22 weeks).

\subsection{Statistical analysis}

Daily breakdown rates $(k)$ were estimated by fitting data to the exponential model: $Y_{t}=Y_{0} \mathrm{e}^{-k t}$, where $Y_{t}$ is the amount of AFDM remaining at time $t$ in days and $Y_{0}$ the initial amount [19]. The $k$ values were determined by using linear regression in the log-transformed relationship. An analysis of covariance (ANCOVA) was used to compare $k$ values among the five streams. An analysis of variance (ANOVA) on log-transformed data followed by Bonferroni's correction was performed to test between-stream differences in peak values of ergosterol and leaf consumption by gammarids.

\section{Results}

\subsection{Leaf breakdown}

In the stream closest to neutrality LM, breakdown of leaf material was significantly faster than in the other streams (ANCOVA, $P<0.05$; Table 2). After 22 weeks, percentages of remaining AFDM were $56.0 \%$ in LM, $71.2 \%$ in the circumneutral HR and more than $83.0 \%$ in the most acidic streams (GS, BR and MR). Covariance analysis showed that breakdown rates were lower and not different from one another in the three acidic streams $\left(k \leqslant 0.00100 \mathrm{~d}^{-1}\right)$ when compared to the neutral ones $\left(k \geqslant 0.00175 \mathrm{~d}^{-1}\right)$.

\subsection{Fungal biomass}

Fig. 1 shows that ergosterol content of beech leaves increased rapidly within the first 6 weeks of the study in 
the five streams. Ergosterol content declined after 6 weeks in LM but remained high in GS, WA and HR for the remainder of the experiment. Beech leaves exposed in MR differed from this general pattern in that ergosterol concentrations increased after 18 weeks. The five streams did not show any significant differences in the maximum concentration of ergosterol attained during the course of the experiment (ANOVA, $F=2.95, P=0.08)$.

Table 2

Exponential breakdown rates of beech leaves exposed in five headwater streams

\begin{tabular}{lllll}
\hline Streams & $\mathrm{pH}$ & $\begin{array}{l}\text { Leaf } \\
\text { breakdown } \\
\text { rate }\left(\mathrm{d}^{-1}\right)\end{array}$ & $\begin{array}{l}\text { Estimated } \\
\text { initial leaf } \\
\text { mass }(\%)\end{array}$ & $R^{2}$ \\
\hline GS & 4.7 & $0.00082^{\mathrm{a}}$ & 97.3 & 0.79 \\
$\mathrm{BR}$ & 4.9 & $0.00100^{\mathrm{a}}$ & 96.8 & 0.73 \\
MR & 5.7 & $0.00105^{\mathrm{a}}$ & 96.7 & 0.81 \\
HR & 6.4 & $0.00175^{\mathrm{b}}$ & 97.2 & 0.73 \\
LM & 7.1 & $0.00358^{\mathrm{c}}$ & 97.3 & 0.95 \\
\hline
\end{tabular}

$\mathrm{GS}=$ Gentil Sapin, $\mathrm{BR}=$ Bas-Rupts, $\mathrm{MR}=$ Moyens-Rupts, $\mathrm{HR}=$ Hauts-Rupts, $\mathrm{LM}=\mathrm{La}$ Maix. Breakdown rates with different superscript letters are significantly different (ANCOVA, $P<0.05) . R^{2}=$ coefficient of determination $(n=18)$.

\subsection{Laboratory consumption experiments}

The results of the consumption experiments did not give any clear evidence that stream acidification affects the palatability of beech leaves for G. fossarum (Fig. 2). In all streams, leaf consumption by gammarids increased with increasing exposure time and levelled off after 10



Fig. 2. Mean consumption of beech leaves conditioned in five headwater streams (GS, BR, MR, HR, LM), by G. fossarum. All values are means of 3 replicates $\pm 1 \mathrm{SD}$. * Means significant differences between streams (ANOVA, $P<0.05$ ).
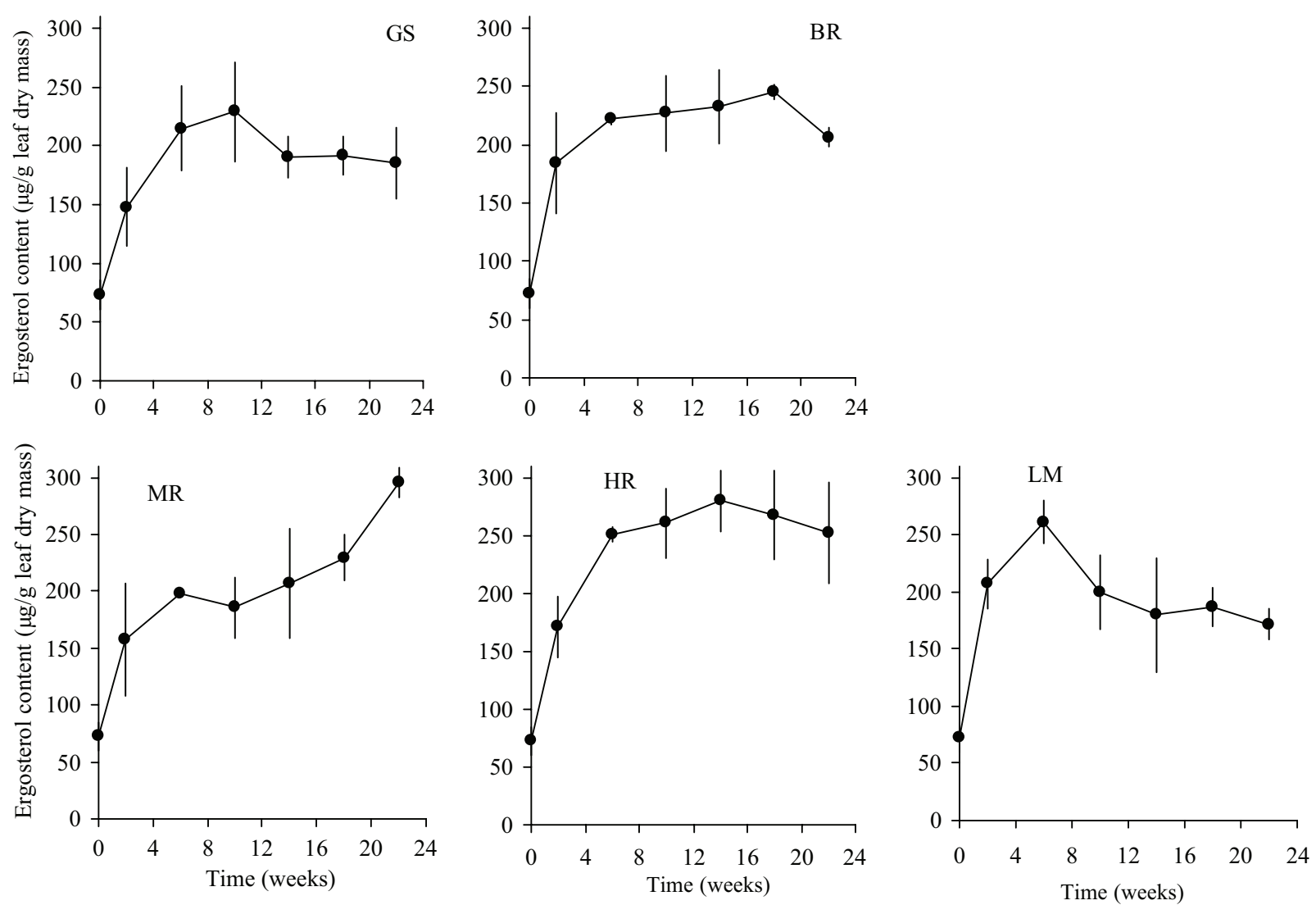

Fig. 1. Dynamics of ergosterol concentrations of aquatic fungi associated with decomposing beech leaves in five headwater streams. All values are means of 3 replicate leaf bags. Vertical bars represent \pm 1 SD. 
weeks' exposure to a mean value 10 times higher than the initial consumption value. The only significant difference between streams occurred by the sixth week of conditioning when gammarids consumed more leaf material from the most neutral stream than from the other streams (ANOVA, $F=27.8, P=0.00002$ ). Consumption rates were generally highly variable within single experiments with standard deviation often approaching $40 \%$.

\section{Discussion}

As the dominant microbial group involved in leaf conditioning, aquatic hyphomycetes are of central importance in the energetics of low-order forest streams [20,21]. Conditioning of substrates exhibiting low palatability and low nutritional values for detritivores, as is the case for beech leaves, is especially important [7]. Fungal biomass determined through ergosterol concentrations has generally been shown to increase to a maximum and then decline during leaf breakdown [22]. In the present study, ergosterol concentration increased and levelled off (GS, BR, HR) or even increased further in the slightly acidic stream (MR). A significant decline only occurred in LM, i.e., the stream least affected by acidic deposition and exhibiting the highest processing rates. Gessner and Chauvet [22] observed a similar pattern of fungal biomass in beech leaves exposed in a Pyrenean softwater stream unaffected by acidic deposition. The absence of a marked peak of fungal biomass within the present 6-month experiment in the four most acidic streams might be partly explained by the very low rates of leaf breakdown $\left(0.00082 \leqslant k \leqslant 0.00175 \mathrm{~d}^{-1}\right)$. In these streams, the end of the breakdown experiment coincided with a time by which leaves had lost $<20 \%$ of their initial mass whereas peaks of fungal biomass on the same or similarly refractory leaf species have been shown to occur later, i.e. when leaf mass loss attained $25-75 \%$ [22].

Although we observed a significant decrease in decomposition rates of beech leaves under acidic conditions, our results do not show any comparable effect on the associated fungal biomass. This is in contrast with previous findings which tend to demonstrate that fungal activity, which governs leaf breakdown to a large extent, is strongly controlled by both internal and external variables, i.e., the nutritional quality of the leaves and the riparian environment, respectively [20]. As examples, low pH [3,23], high aluminium concentrations [24] and low nutrient levels [25] are known to have a negative effect on fungal communities associated with decaying leaves under natural conditions. In particular, Griffith and Perry [25], whose study was comparable to ours, found significantly reduced fungal biomass associated with decomposing oak leaves (Quercus alba L.) in a strongly acidified West Virginia stream $(\mathrm{pH}=4.3)$. In the present study, even leaves exposed in the most acidified stream (GS) which had low $\mathrm{pH}$ (down to 4.3) and high total aluminium concentrations (up to $900 \mu \mathrm{g} / \mathrm{L}$ ) did not show lower fungal biomass concentrations. This might be partly explained by the relatively high concentrations of atmospheric-derived nitrates in GS $(6.7 \mathrm{mg} / \mathrm{L})$ which provided inorganic $\mathrm{N}$ usable for fungal production [21] and thus compensated for the unfavorable acidic conditions prevailing in this stream.

An alternative explanation may be that acidic conditions affected the metabolism of aquatic hyphomycetes but not their biomass. Kok et al. [23] showed that aerial fungi associated with floating Nymphaea alba L. could develop at low $\mathrm{pH}$ (4.0), but that maceration was only observed at $\mathrm{pH} 5.5$ or 7.5. The authors supposed that inhibition of pectin degradation, a key process in leaf decomposition [26] could be an important factor causing the suppression of leaf decomposition at low $\mathrm{pH}$. This is in agreement with the fact that pectinases have neutral to alkaline optima [26]. On the other hand, Thompson and Bärlocher [14] observed maximum leaf mass loss due to the microbial activity at pH 6.0 compared to that occurring at lower or higher $\mathrm{pH}$, and argued that fungal polygalacturonases, cellulases and hemicellulases are generally more active under slightly acidic conditions. Moreover, peaks of decompositional activity of aquatic hyphomycetes in relation to $\mathrm{pH}$ appear to be largely species-specific and changes in $\mathrm{pH}$ also influence the composition of the fungal community [14]. Whatever the involved process(es), no leaf maceration could lead to a decrease in leaf palatability for detritivores, which was not observed in the present study except for one date, i.e. after 6 weeks' exposure. Even if the leaf consumption experiment was weakened by the substantial variability in response between groups of individuals, it provides no strong evidence that leaf conditioning by aquatic fungi was affected by water acidification. We thus believe that stream acidification greatly affected neither direct nor indirect contribution of aquatic hyphomycetes to leaf decomposition in the present study. This is in agreement with previous results from the same streams, which suggested that the inhibition of leaf decomposition in acidic streams was mainly due to an alteration of the detritivore communities [1]. Especially, the absence of the acid-sensitive species $G$. fossarum from the acidic streams, mainly explains the different breakdown rates observed (see Ref. [1] or further discussion).

This study provides some indications that the reduced decomposition of beech leaves in acidified streams of the Vosges Mountains was not primarily due to changes in fungal biomass. As the relative importance of the different variables ( $\mathrm{pH}, \mathrm{Al}$ and nutrients) related to the toxicity of acidified waters is still not well established, further manipulations including a large set of streams 
are needed to clarify the complex effects of acidification on fungal communities. For this purpose, studies at different levels of organization or process (e.g. fungal community; fungal biomass production, fungal enzymatic activity, invertebrate consumption) are essential.

\section{Acknowledgements}

The authors are grateful to C. Saint-Criq for technical assistance during ergosterol analysis, F. Guérold who was involved in the design of this study and E. Pattee for linguistic revision of the manuscript. They also thank three anonymous referees for useful comments on the manuscript.

\section{References}

[1] Dangles O, Guérold F. Influence of shredders in mediating breakdown rates of beech leaves in circumneutral and acidic forest streams. Arch Hydrobiol 2001;151:649-66.

[2] Mulholland PJ, Driscoll CT, Elwood JW, Osgood MP, Palumbo AV, Rosemond AD, Smith ME, Schofield C. Relationship between stream acidity and bacteria, macroinvertebrates and fish: a comparison of north temperate and south temperate mountain streams, USA. Hydrobiologia 1992;239:7-24.

[3] Chamier A-C. Effect of $\mathrm{pH}$ on microbial degradation of leaf litter in seven streams of the English Lake District. Oecologia 1987;71:491-500.

[4] Groom AP, Hildrew AG. Food quality for detritivores in streams of contrasting pH. J Anim Ecol 1989;58:863-81.

[5] Meegan SK, Perry SA, Perry WB. Detrital processing in streams exposed to acidic precipitation in the Central Appalachian Mountains. Hydrobiologia 1996;339:101-10.

[6] Tuchman NC. Relative importance of microbes versus macroinvertebrate shredders in the process of leaf decay in lakes of differing pH. Can J Fish Aquat Sci 1993;50:270712.

[7] Bärlocher F, Kendrick B. Role of aquatic hyphomycetes in the trophic structure of streams. In: Wicklow DT, Carrol GC, editors. The fungal community: its organization and role in the ecosystem. New York: Marcel Dekker, 1981. p. 743-60.

[8] Rosset J, Bärlocher F. Aquatic hyphomycetes: influence of $\mathrm{pH}, \mathrm{Ca}^{2+}$, and $\mathrm{HCO}_{3}$ on growth in vitro. Trans Brit Mycol Soc 1985;84:137-45.

[9] van Frankenhuyzen K, Geen GH. Microbe-mediated effect of low pH on availability of detrital energy to a shredder, Clistoronia magnifica (Trichoptera, Limnephilidae). Can J Zool 1986;64:421-6.

[10] Bärlocher F, Rosset J. Aquatic hyphomycete spora of two Black Forest and two Swiss Jura streams. Trans Brit Mycol Soc 1981;76:479-83.

[11] Dubey T, Stephenson SL, Edwards PJ. Effect of $\mathrm{pH}$ on the distribution and occurrence of aquatic fungi in 6 WestVirginia Mountain streams. J Environ Qual 1994;23: 1271-9.
[12] Suberkropp K, Klug JM. The maceration of deciduous leaf litter by aquatic hyphomycetes. Can J Bot 1980;58:1025-31.

[13] Bärlocher F, Petersen RC. Aquatic hyphomycetes in an acidified and limed humic stream in Sweden. Verh Int Ver Limnol 1988;23:1279-86.

[14] Thompson PL, Bärlocher F. Effect of pH on leaf breakdown in streams and in the laboratory. J N Am Benthol Soc 1989;8:203-10.

[15] Brakke DF, Baker JP, Bohmer J, Hartmann A, Havas M, Jenkins A, Kelly C, Ormerod SJ, Paces T, Putz R, Rosseland BO, Schindler DW, Segner H. Physiological and ecological effects of acidification on aquatic biota. In: Steinberg CEW, Wright RF, editors. Acidification of freshwater ecosystems: implication for the future. Chichester: Wiley, 1994. p. 275-312.

[16] Dambrine E, Pollier B, Poswa A, Ranger J, Probst A, Viville D, Biron P, Granier A. Evidence of current acidification in spruce stands in the Vosges Mountains, North-Eastern France. Water Air Soil Pollut 1998;105:4352.

[17] Dangles O, Guérold F, Usseglio-Polatera Ph. Role of drifted particulate organic matter in the macroinvertebrate colonization patterns of leaf bags in headwater streams. Freshwater Biol 2001;46:575-86.

[18] Gessner MO, Newell SY. Biomass, growth rate, and production of filamentous fungi in plant litter. In: Hurst CJ, Crawford RL, Knudsen G, McInerney M, Stetzenbach LD, editors. Manual of environmental microbiology. 2nd Ed.),. Washington, DC: ASM Press, 2002. p. 390-408.

[19] Petersen RC, Cummins KW. Leaf processing in a woodland stream. Freshwater Biol 1974;4:343-68.

[20] Gessner MO, Suberkropp K, Chauvet E. Decomposition of plant litter by fungi in marine and freshwater ecosystems. In: Wicklow DT, Söderström B, editors. The Mycota: a comprehensive treatise on fungi as experimental systems for basic and applied research. Vol. IV: environmental and microbial relationships. Berlin: Springer, 1997. p. 303-22.

[21] Suberkropp K. Effect of dissolved nutrients on two aquatic hyphomycetes growing on leaf litter. Mycol Res 1998;102:998-1002.

[22] Gessner MO, Chauvet E. Importance of stream microfungi in controlling breakdown rates of leaf litter. Ecology 1994;75:1807-17.

[23] Kok CJ, Haverkamp W, Vanderaa HA. Influence of pH on the growth and leaf-maceration ability of fungi involved in the decomposition of floating leaves of Nymphaea alba in an acid water. J Gen Microbiol 1992;138:103-8.

[24] Chamier A-C, Tipping E. Effects of aluminum in acid streams on growth and sporulation of aquatic hyphomycetes. Environ Pollut 1997;96:289-98.

[25] Griffith MB, Perry SA. Fungal biomass and leaf litter processing in streams of different water chemistry. Hydrobiologia 1994;294:51-61.

[26] Jenkins CC, Suberkropp K. The influence of water chemistry on the enzymatic degradation of leaves in streams. Freshwater Biol 1995;33:245-53. 